\title{
PENGARUH KUALITAS LAYANAN-E, KEPUASAN-E, DAN KEPERCAYAAN-E TERHADAP KESETIAAN-E PADA GOJEK.
}

Margaretha Pink Berlianto,

Jurusan Manajemen, Universitas Pelita Harapan

margaretha.berlianto@uph.edu

\begin{abstract}
ABSTRAK
Bisnis penyedia layanan daring berkembang dengan pesat saat ini dan diikuti dengan persaingan sengit antar penyedia layanan daring. Merupakan hal yang sangat penting bagi mereka untuk bertahan dan menang dalam persaingan bisnis ini. Untuk itu perlu diidentifikasikan mengenai apa saja kualitas layanan dari situs tersebut yang menjadi perhatian pelanggan, mengetahui seberapa jauh kepuasan, seberapa dalam tingkat kepercayaan dan seberapa jauh kesetiaan pelanggan terhadap situs penyedia layanan daring tersebut. Tujuan dari penelitian ini adalah mengetahui kualitas layanan elektronik, kepuasan, kepercayaan dan kesetiaan pelanggan Gojek. Penelitian ini dilakukan terhadap pengguna layanan Gojek (Go-ride) dengan menyebarkan 400 kuisioner di area Jakarta dan Tangerang dan terdapat 121 kuisioner yang dapat digunakan. Masing-masing peubah diukur dengan 5 skala Likert. Pengujian kesahihan menggunakan nilai factor loading sebesar $\geq 0,6$ dan pengujian keandalan dengan menggunakan composite reliability dengan nilai $\geq 0,7$ dan nilai variance extracted $\geq 0,50$. Pada penelitian ini terdapat empat belas hipotesis. Pengujian uji kecocokan model dan hipotesis dilakukan dengan analisa SEM. Hasil dari penelitian ini adalah Ease of use, E-scape, Responsiveness, Customization dan Assurance yang merupakan kelima kualitas layanan elektoronik yang digunakan pada penelitian ini tidak berpengaruh positif terhadap e-satisfaction, e-satisfaction berpengaruh pada $e$-trust, e-trust tidak berpengaruh terhadap behavioral loyalty, affective loyalty, cognitive loyalty dan conative loyalty dan e-satisfaction berpengaruh terhadap behavioral loyalty, affective loyalty, cognitive loyalty dan conative loyalty.
\end{abstract}

Kata Kunci: Kualitas layana-e, kepuasan-e, keperrcayaan-e, kesetiaan-e, perdagangan-e.

\section{ABSTRACT}

Daring service provider business is growing rapidly at this time, followed by fierce competition between daring service providers. It is very important for them to survive and win in this business competition. For that, they need to identify their service quality from their site based on customers' perception, knowing the satisfaction of their customers, how deep the trust of their customers and how extent of their customer loyalty toward the daring service providers. The purpose of this study is to analyze e-service quality, e-satisfaction, e-trust and e-customer loyalty of Gojek. The research was conducted on service users Gojek (Go-ride) by distributing 400 questionnaires in Jakarta and Tangerang area and there were 121 questionnaires that can be used. Each peubahs was measured with 5 Likert scale. In this study, the validity test was using factor loading value of $\geq 0.6$ and the reliability test was using the composite reliability $\geq 0.7$ and variance extracted $\geq 0.50$. There were fourteen hypotheses was tested in this study. The model fit and hypothesis testing was done by using SEM. The results of this study are Ease of use, E-scape, Responsiveness, Customization and Assurance which are five dimension of e-service quality that used in this study had no positive effect on e-satisfaction, e-satisfaction had an effect on e-trust, e-trust had no effect on behavioral loyalty, affective loyalty, loyalty cognitive and conative loyalty and e-satisfaction had effect on behavioral loyalty, affective loyalty, loyalty cognitive and conative loyalty.

Keywords: e-service quality, e-satisfaction, e-trust, e-loyalty, e-commerce. 


\section{PENDAHULUAN}

Saat ini, layanan daring bertumbuh sangat pesat. Hal ini dikarenakan layanan berbasis web atau layanan daring memberikan banyak keuntungan dan kemudahanan bagi konsumen dan didukung oleh perkembangan terknologi internet yang memadai. Keuntungan yang diberikan dari layanan daring atau layanan-e ini, antara lain seperti kemudahan dalam menggunakan, meningkatkan kendali dari konsumen, mengurangi biaya transaksi dan lainnya (Scullion \& Nicholas, 2001; Unsal \& Hormoz, 2001; Zeithaml, 2002). Keuntungan-keuntungan tersebut mengakibatkan bisnis pemberi layanan daring berkembang pesat dan menjadi pemimpin dalam industri jasa (Yang \& Fang, 2004). Penyedia layanan bisnis daring yang semakin banyak ini mengakibatkan kompetisi yang sengit diantara penyedia bisnis daring tersebut (Yang \& Fang, 2004). Penyedia layanan dari toko daring, yang semula hanya menjual produk menjadi berkembang sebagai penyedia layanan dalam bentuk jasa, seperti jasa layanan transportasi motor, jasa layanan transportasi mobil, jasa layanan kebersihan, dan lainnya.

Terdapat beberapa jasa layanan yang sedang bertumbuh pesat di Indonesia, khususnya Jakarta seperti Tokobagus.com, Berniaga.com, Elevenia.com, Traveloka.com,
Tokopedia.com, Blibli.com, Olx.com, Lazada.com, Bukalapak.com, Trivago.com (CSR Indonesia, 2015) dan jasa layanan transportasi seperti Go-jek, Grabbike, Grabtaxi, Uber, Bajaj App, Ttransjek, Wheel Line, Bangjek, Ojek Syar'I dan Blue-Jek (Okezone, 2015). Pada penelitian ini lebih berfokus pada Gojek, khususnya jasa layanan go-ride. Pemilihan Gojek dilakukan karena Gojek adalah penyedia layanan transportasi ojek daring pertama di Indonesia dan memiliki jumlah pengendara terbanyak dibandingkan dengan pesaingnya, seperti Grabbike.

Untuk berhasil dan bertahan dalam kompetisi yang sengit ini, penyedia layanan daring harus memiliki keunggulan kompetitif dan memberikan kualitas layanan yang superior, yang lebih baik daripada layanan yang diberikan oleh pesaingnya (Yang \& Fang, 2004). Untuk itu, penyedia layanan daring harus mengetahui apa saja kualitas layanan daring (kualitas-e) yang dianggap penting oleh konsumen dan bagaimanan kualitas layanan daring yang mereka berikan selama ini di mata konsumen. Dengan memberikan kualitas layanan yang baik, pelanggan menjadi puas dan percaya sehingga mengakibatkan mengingkatnya kesetiaan pelanggan. Membuat pelanggan puas merupakan tantangan bisnis pada pasar yang kompetitif saat ini. 
Perkembangan toko daring dan layanan daring yang tumbuh dengan pesat ini membuat banyak praktisi dan akademisi di bidang ini berfokus bagaimana meningkatkan layanan daring untuk menarik pelanggan dan bagaimana mempertahankan pelanggan tersebut (Jun, Yang, \& Kim, 2004). Beberapa hal telah dilakukan oleh peneliti terdahulu mengenai hal ini, seperti perusahaan harus fokus pada layanan daring yang meliputi semua hal atau kegiatan yang terjadi sebelum, selama, dan sesudah transaksi (Zeithaml, 2002), memberikan berbagai benefit seperti kenyamanan dalam memesan produk atau jasa, dapat memeriksa ketersediaan barang atau jasa secara instan, dapat menemukan harga yang kompetitif dan ketersediaan informasi dari keputusan pembelian (Jun et al., 2004). Selain memberikan layanan yang baik, juga penting untuk meningkatkan kepercayaan pelanggan karena kepercayaan merupakan faktor penting dalam interaksi bisnis-pelanggan dan merupakan aspek penting dalam perdagangan elektronik (GrabnerKräuter \& Faullant, 2008). Salah satu alasan mengenai pentingnya kepercayaan pada perdagangan elektronik adalah dalam lingkungan virtual memiliki tingkat ketidakpastian yang lebih tinggi dalam transaksi ekonomi yang dapat membawa beberapa resiko yang dapat disebabkan oleh ketidakpastian implisit karena menggunakan infrastruktur teknologi terbuka untuk pertukaran informasi atau resiko karena perilaku individu yang terlibat dalm transaksi daring (Grabner-Kräuter \& Faullant, 2008).

Selain kualitas layanan daring, kepuasan dan kepercayan, kesetiaan pelanggan juga perlu mendapatkan perhatian dan ditingkatkan. Karena dengan adanya kesetiaan pelanggan, perusahaan dapat menciptakan keunggulan kompetitif, dapat meningkatkan pangsa pasar dan laba perusahaan dalam jangka panjang, mengurangi biaya pemasaran seperti biaya promosi, untuk itu perusahaan tidak hanya semata mengembangkan program pemasaran tetapi juga perlu memelihara hubungan jangka panjang untuk menciptakan kesetiaan pelanggan (Utami, 2015).

Penelitian ini mengadopsi penelitian yang dilakukan oleh (Ribbink, et al., 2004) mengenai pengaruh ekualitas, e-kepercayaan, e-kepuasan terhadap e-kesetiaan pada mahasiswa yang pernah melakukan pembelian buku dan CD secara daring di Eropa, penelitian yang dilakukan oleh Chou, Chen, \& Lin (2015) mengenai pengaruh pengalaman daring, kepedulian daring, e-kepuasan, dan $e$-trust terhadap kesetiaan-e terhadap pembeli pakaian daring wanita di Taiwan, dan penelitian yang dilakukan 
oleh El-Manstrly \& Harrison (2013) mengenai pengaruh kepercayaan terhap kesetiaan kognitif, kesetiaan afektif, kesetiaan konatif dan loyalita perilaku atau tindakan pada konsumen bank di Inggris. Dimensi dari kualitas layanan pada toko tradisional telah diketahui dengan pasti dan telah terbentuk dengan sangat jelas. Akan tetapi kualitas layanan dari layanan daring belum terbentuk dengan pasti dan belum mendapatkan konsensus mengenai dimensi layanan daring yang pasti. Penelitian ini bertujuan unutk mengidentifikasikan dimensi kunci kualitas jasa/layanan elektronik yang terpresepsi oleh pelanggan daring. Selain itu juga untuk mengetahui hubungan antara dimensi kualitas jasa elektronik dan kepuasan pelanggan, khususnya pelanggan Gojek dan mengukur hubungan antara kepuasan dan kepercayaan dari pelanggan daring, dalam hal ini pelanggan Gojek dan mengukur hubungan antara kepuasan, kepercayaan dan keempat dimensi dari kesetiaan pelanggan Gojek.

\section{TINJAUAN LITERATUR}

\section{Kualitas-e}

Cara pelanggan merasakan kualitas layanan pada lingkungan situs atau daring berbeda dengan layanan tradisional(Amin, 2016). Model kualitas layanan pada konteks tradisional mengukur kualitas layanan pada lima dimensi, yaitu berwujud, daya tanggap, kandalan, jaminan dan empati (Parasuraman, Zithaml, \& Berry, 1988). Model ini digunakan untuk mengukur kualitas layanan pada konteks toko tradisional atau offline. Layanan daring memiliki karakteristik unik yang tidak dihadapi oleh layanan offine, seperti masalah server, cadangan informasi, masalah konektivitas dan lainnya (Collier \& Bienstock, 2006). Kualitas layanan elektronik dapat didefinisikan sebagai sejauh mana sebuah situs dapat memfasilitasi pembelanjaan, pembelian dan pengiriman yang efektif dan efisien (Zeithaml, 2002).

Pada penelitian terdahulu menemukan bahwa tidak semua dimensi kualitas jasa memiliki dampak yang sama terhadap kepuasan (Jun et al., 2004). Sehingga merupakan hal yang penting untuk mengindentifikasikan dimensi mana yang lebih penting dibandingkan dengan dimensi lainnya untuk meningkatkan kualitas layanan elektronik yang dirasakan oleh pelanggan. Dalam penelitian ini, menggunakan 5 (lima) dimensi dari kualitas-e yang diadopsi dari Ribbink, Riel, Liljander, \& Streukens (2004) yaitu kemudahan penggunaan(ease of use), $e$ scape atau website design, kostumisasi, daya tanggap (responsiveness), dan jaminan (assurance). Penggunaan kelima dimensi ini didasarkan oleh penelitian terdahulu terhadap pembeli daring 
wanita yang menunjukkan bahwa terdapat dua faktor yang dirasakan oleh pelanggan ketika berbelanja di situs yaitu pelanggan daring peduli terhadap keamanan dan privasi dan pengalaman dari konsumen daring, seperti rancangan situs dan efisiensi dalam pengiriman (Garbarino \& Strahilevitz, 2004).

Menurut Venkatesh \& Davis (2000), kemudahan penggunaan merupakan unsur penting ketika pelanggan menggunakan teknologi komputer dan menjadi sesuatu yang penting bagi pengguna baru dari teknologi tersebut. Persepsi mengenai kemudahan penggunaan mencerminkan bagaimana sederhananya sebuah situs digunakan (Corritore, Kracher, \& Wiedenbeck, 2003). MenurutReibstein (2002), kemudahan penggunaan terdiri dari fungsi yang tersedia, kemudahan dalam mengakses informasi, kemudahan dalam pemesanan dan navigasi. Sedangkan menurut Davis (1989), kemudahan penggunaan berfokus pada bagaimana mudahnya pengguna dapat mencapai tujuan mereka dalam menggunakan komputer.

Menurut Ribbink et al.(2004), situs perusahaan daring juga harus dapat enak dilihat. Oleh karena itu E-scape atau websitedesign sangatlah penting. Desain situs secara langsung berhubungan dengan interface. Menurut Ganguly, Dash, \& Cyr(2009), jika interface pada sebuah situs terstruktur dengan buruk, kurangnya keamanan dan kejelasan atau terdapat gangguan maka transaksi yang terjadi dapat terganggu. Idealnya sebuah situs dapat menyediakan informasi yang jelas, seperti navigasi yang mudah dan tingkat kompleksitas yang rendah (Kesharwani \& Bisht, 2012).

Sebuah situs pembelian yang baik adalah situs yang dapat dikostumisasi berdasarkan kebutuhan pelanggan. Menurut Srinivasan, Anderson, \& Ponnavolu (2002), Toko daring harus berjuang untuk melakukan kostumisasi terhadap layanannya agar memenuhi kebutuhan pelanggan. Daya tanggap merupakan dimensi yang penting dalam kualitas layanan, baik kualitas layanan offline maupun kualitas layanan oline. Responsiveness mengukur kemampuan sebuah perusahaan untuk menyediakan informasi kepada pelanggan ketika terjadi masalah, memiliki mekanisme menanggani pengembalian dan memberikan jaminan daring (Zeithaml, 2002). Jaminan adalah persepsi pelanggan mengenai keamanan yang dirasakan dan privasi ketika pelanggan menggunakan layanan daring tersebut. Keamanan dan privasi merupakan hal yang diperhatikan dengan serius oleh pelanggan daring. Dalam lingkungan elektronik,kebutuhan konsumen untuk pengendalian dan 
perlindungan privasi cukup tinggi (Rust \& Kannan, 2003). Faktor keamanan yang menjadi kepedulian dari pelanggan adalah resiko pihak ketiga untuk mendapatkan informasi penting pelanggan, seperti akses terhadap kartu kredit atau detail dari akun bank (Milne \& Rohm, 2000). Privasi membahas masalah perlindungan terhadap infomasi mengenai identitas individu di internet (Mukherjee \& Nath, 2007). Kebijakan privasi dari toko daring melibatkan adopsi dan pelaksanaan kebijakan privasi, pemberitahuan, pengungkapan, dan pilihan atau persetujuan dari konsumen (Bartet al., 2005). Privasi terjadi ketika pelanggan dapat membatasi penggunaan informasi personal mereka (Ribbink et al., 2004). Konsumen mengharapkan peritel daring memiliki kebijakan yang terlihat bahwa mereka tidak akan membocorkan atau menjual informas pribadi konsumennya (Mukherjee \& Nath, 2007).

\section{e-Kepuasan}

Menurut Oliver (1999), kepuasan adalah tingkat sebuah kebutuhan dipenuhi pada pembelian akhir. Kepuasan adalah sebuah evaluasi mengenai bagaimana sebuah retailer dapat memenuhi atau melebihi ekspektasi dari pelanggan (Levy, Weitz, \& Beitelspacher, 2011). Menurut Hansemark \& Albinsson (2004), kepuasan adalah sikap keseluruhan pelanggan terhadap penyedia layanan atau reaksi emosional terhadap perbedaan antara antisipasi mereka dengan yang mereka terima mengeenai pemenuhan beberapa kebutuhan, tujuan dan keinginan. Menurut Anderson \& Srinivasan (2003), e-kepuasan adalah keridhaan pelanggan sehubungan dengan pengalaman pembelian sebelumnya dengan perusahaan e-commerce. E-kepuasan mengukur tingkat evaluasi pelanggan secara keseluruhan pada pengalaman pembelian daring (Gounaris, Dimitriadis, \& Stathakopoulos, 2010). Sedangkan menurut Szymanski \& Hise (2000), ekepuasan dilihat sebagai konstruk keseluruhan yang mencerminkan efek kumulatif dari serangkaian pengalaman yang berbeda dengan penyedia layanan selama periode waktu. Pada peneitian ini mengunakan definisi e-kepuasan dari Anderson \& Srinivasan (2003).

\section{e-Kepercayaan}

Pelangan selalu memiliki kekhawatiran ketika membeli barang secara daring karena pembelian daring sangat penuh ketidakpastian (Chou et al., 2015; Shukla, 2014). Sehingga, kepercayaan merupakan masalah yang penting dalam konteks toko daring (Papadopoulouet al., 2001) dan faktor penting dalam berbagai interaksi sosial yang melibatkan ketidakpastian dan ketergantungan (Grabner-Kräuter \& Faullant, 2008). Kepercayaan merupakan pusat dari 
transaksi ekonomi, baik dilakukan pada toko retail secara offline atau melalui internet, yaitu situs (Grabner-Kräuter \& Faullant, 2008). Kepercayaan timbul dari proses yang panjang. Jika terdapat kepercayaan antara pelanggan dan perusahaan maka hubungan kerjasama akan lebih mudah (Utami, 2015). Kepercayaan lebih dibutuhkan pada siuasi pembelian secara daring (Pavlou \& Fygenson, 2006).

\section{E-kepercayaan dapat}

didefinisikan sebagai sebuah sikap dari harapan yang percaya dalam situasi resiko daring bahwa seorang rentan untuk tidak akan dieksploitasi (Corritore et al., 2003). Komiak \& Benbasat (2004) melihat kepercayaan dari pandangan emosional. Ia mendefinisikan kepercayaan sebagai sejauh mana seseorang merasa aman dan percaya diri terhadap orang yang dipercaya. Sedangkan Ennew \& Sekhon (2007) melihat kepercayaan dari pandangan emosional dan dimensi kognitif, mendefinisikan kepercayaan sebagai kesediaan seseorang untuk menerima kerentanan atas dasar harapan positif mengenai niat atau perilaku dalam situasi yang dikarakteristikan oleh dengan saling ketergantungan dan risiko. Pada penelitian ini menggunakan definisi ekepercayaan dari Corritore et al. (2003).

\section{Kesetiaan-e}

Terdapat perbedaan sikap atau perilaku pembelian antara pelanggan offline dengan pelanggan daring. Pelanggan daring dapat mengunjungi toko daring dan membeli produk dengan bebas tanpa harus membeli produk lainnya di toko yang sama (Chou et al., 2015). Hal ini membuat kesetiaan-e menjadi masalah penting bagi pihak bisnis daring karena pelanggan dengan mudahnya dapat berpindah dari satu toko daring ke toko daring lainnya dan dapat membandingkan produk yang sama pada beberapa toko (Lu, Chang, \& Yu, 2013).

Definisi e-loyalty menurut Srinivasan et al. (2002) adalah sikap yang menguntungkan pelanggan dan komitmennya terhadap peritel daring yang menghasilkan perilaku pembelian ulang. Pelanggan yang benar-benar loyal adalah pelanggan yang berkomitmen dan melekat (attachment) dengan retailer tersebut dan tidak mudah untuk diganggu oleh alternatif yang lebih menarik (Shankar, Smith, \& Rangaswamy, 2003). Menurut Cyr (2008), kesetiaan-e adalah niat pelanggan untuk mengunjungi kembali sebuah situs web dan mempertimbangkan untuk membeli dari situs tersebut di masa depan.

Menurut Oliver(1997), kesetiaan layanan dapat dibagi menjadi 4 dimensi yaitu kesetiaan kognitif, loyaltas afektif, kesetiaan konatif, dan kesetiaan tindakan. Kesetiaan kognitif atau 
kesetiaan berdasarkan kepercayaan terhadap merek merupakan tingkat pertama dari loyaltitas. Pada tingkat kesetiaan kognitif informasi merek yang diterima oleh konsumen mengindikasikan bahwa mereka tersebut lebih disukai dibandingkan dengan alternatif yang ada. Kesetiaan kognitif fokus pada aspek kinerja dari produk (Oliver, 1999). Tingkat kesetiaan yang kedua adalah kesetiaan afektif, dimana kesetiaan diperoleh sebagai akumulasi dari kepuasan atas penggunaan merek tertentu. Kesetiaan afektif mengarah pada kesukaan terhadap merek (Oliver, 1999). Kesetiaan konatif adalah kesetiaan yang terjadi karena dipengaruhi oleh pengulangan secara positif terhadap pembelian suatu merek. Pada dimensi ini, kesetiaan berfokus pada pembelian ulang merek tersebut (Oliver, 1999). Tingkat kesetiaan yang keempat adalah kesetiaan aksi atau behavioral loyalty, yaitu pelanggan berkomitmen untuk membeli kembali (Oliver, 1999). Dimensi ini mengacu kepada perilaku pembelian kembali pelanggan dan mengindikasikan preferensi mereka terhadap merek atau layanan (Garland \& Gendall, 2004). Sehingga, dimensi kesetiaan perilaku penting bagi perusahaan untuk meningkatkan laba (Kumar \& Shah, 2004).
Pada penelitian ini mengunakan keempat tahap atau dimensi yang diperkenalkan oleh Oliver (1999) untuk menginvestigasi seberapa jauh dimensi kesetiaan yang dimiliki oleh pelanggan terhadap Gojek.

\section{Hubungan antara kualitas-e dan $e$ - satisfaction.}

Penelitian terdahulu menemukan bahwa terdapat hubungan antara kualitas layanan dan kepuasan pelanggan. Kualitas layanan merupakan anteseden dari kepuasan pelanggan (Kang, Cho, \& Baek, 2007). Pada penelitian ini terdapat 5 dimensi kualitas layanan daring yang mempengaruhi kepuasaan, yaitu kemudahan penggunaan, design situs atau e-scape, kostumisasi, daya tanggap dan jaminan.

MenurutDabholkar et al., (1996)kemudahan penggunaan adalah penentu kualitas pelayanan dan juga sebagai antecenden dari kepuasan pelanggan(Xue \& Harker, 2002).Kemudahan penggunaan dari sebuah aplikasi daring yang disediakan oleh penyedia layanan dapat mengingkatkan efisiensi dalam menggunakan layanan tersebut(Xue \& Harker, 2002). Menurut Cyr (2008), design situs yang baik merupakan faktor kunci meningkatnya kepuasan pelanggan. Design situs yang baik membantu pelanggan menelusuri situs 
dengan mudah, layout yang baik membuat pelanggan merasa bahagia dan puas (Shukla, 2014). Selain itu, menurut Zeithaml et al. (2000), pada umumnya daya tanggap memiliki pengaruh positif terhadap e-satisfaction. Menurut Ribbink et al.(2004), dimensi jaminan terdiri dari persepsi keamanan pelanggan dan privasi. Sekuriti dan privasi adalah merupakan hal yang penting bagi pelanggan e-service (Rust \& Kannan, 2003). Keamanan berkaitan dengan kepedulian pihak ketiga mengenai risiko. Berdasarkan uraian diatas, maka:

H1: Ease of Use berpengaruh positif terhadap e-satisfaction.

$\mathrm{H} 2$ : E-scape berpengaruh positif terhadap e-satisfaction.

H3: Responsiveness berpengaruh positif terhadap e-satisfaction.

H4: Customization berpengaruh positif terhadap e-satisfaction.

H5: Assurance berpengaruh positif terhadap e-satisfaction .

Hubungan antara $e$-satisfaction dan $e$ trust

Kepuasan pelanggan merupakan hal yang sangat penting dalam hubungan antara penjual dan pembeli (Wulf, et al., 2001). Kepuasan merupakan hasil dari interaksi masa lalu yang menghasilkan penguatan pengulangan yang positif (Hennig-Thurau, et al., 2002). Dalam konteks lingkungan berbasis web, kepercayaan pelanggan tetap merupakan hal yang relevan dan memainkan peranan penting dalam keberhasilan pengelolaan bisnis elektronik (Ibrahim, Noor, \& Mehad, 2009). Dalam industri jasa layanan, kepuasan pelanggan berpengaruh positif terhadap kepercayaan. Hal ini didukung oleh penelitan yang dilakukan oleh Yapet al, (2012) terhadap konsumen bank di Malaysia, penelitian terhadap pelanggan restoran (Bowden-Everson, Dagger, \& Elliott, 2013). Berdasarkan uraian diatas, maka:

H6: E-satisfaction berpengaruh terhadap e-trust.

Hubungan antara Kepercayaan-e dan Kesetiaan-e

Ketika pelanggan merasakan kepercayaan dari sebuah toko daring, mereka akan merasa nyaman dan percaya diri ketika berbelanja di toko tersebut (Connolly \& Bannister, 2007). Pelanggan tersebut akan melanjutkan untuk berbelanja di situs yang sama sehingga menyebabkan kesetiaan yang lebih tinggi (Liu, et al., 2005). Kepercayaan mengurangi ketidakpastian pelanggan dan kerentanan dalam konteks jasa tidak berwujud (Bowden-Everson et al., 2013). Menurut beberapa penelitian sebelumnya menemukan bahwa kepercayaan berhubungan positif terhadap kesetiaan, seperti penelitian yang dilakukan oleh Yap et al. (2012) pada industi bank di Malaysia dan 
penelitian Chou et al. (2015) terhadap pembelian daring pakaian di Taiwan. Akan tetapi menurut penelitian yang dilakukan oleh Herington \& Weaven (2007) terhadap pengguna daring banking di Australia, tidak ada hubungan antara e-trust dan e-loyalty. Berdasarkan uraian diatas, maka:

H7: E-trust berpengaruh terhadap behavioral loyalty.

H8: E-trust berpengaruh terhadap affective loyalty.

H9: E-trust berpengaruh terhadap cognitive loyalty.

H10: E-trust berpengaruh terhadap conative loyalty.

Hubungan antara Kepuasan-e dan Kesetiaan-e

Terdapat hubungan positif antara kepuasan pelanggan dan kesetiaan pelanggan (Tam, 2012). Ketika pelanggan puas dengan sebuah situs, mereka akan bersedia untuk lebih berinteraksi dengan situs tersebut dimasa mendatang dan menjadi pelanggan yang loyal (Fang, Chiu, \& Wang, 2011). Dengan berjalananya waktu, kepuasan akan berubah menjadi kesetiaan
(Kursunluoglu, 2014). Akan tetapi, tidak semua kepuasan akan mempengaruhi kesetiaan dalam beberapa keadaan (Miranda, Kónya, \& Havrila, 2005). Menurut penelitan yang dilakukan oleh (Chou et al., 2015) terhadap pembeli pakaian daring di Taiwan dan penelitian yang dilakukan oleh Amin (2016) terhadap pengguna internet banking di Malaysia menunjukkan bahwa ekepuasan berpengaruh positif terhadap kesetiaan. Hal ini juga didukung oleh penelitian yang dilakukan oleh Suhartanto (2011) pada industri perhotelan di Indonesia yang menyatakan bahwa kepuasan pelanggan dipengaruhi kesetiaan kognitif, kesetiaan afektif dan kesetiaan konatif. Berdasarkan uraian diatas, maka:

H11: E-satisfaction berpengaruh terhadap behavioral loyalty.

H12: E-satisfaction berpengaruh terhadap affective loyalty.

H13: E-satisfaction berpengaruh terhadap cognitive loyalty.

H14: E-satisfaction berpengaruh terhadap conative loyalty. 


\section{Rerangka Konseptual}

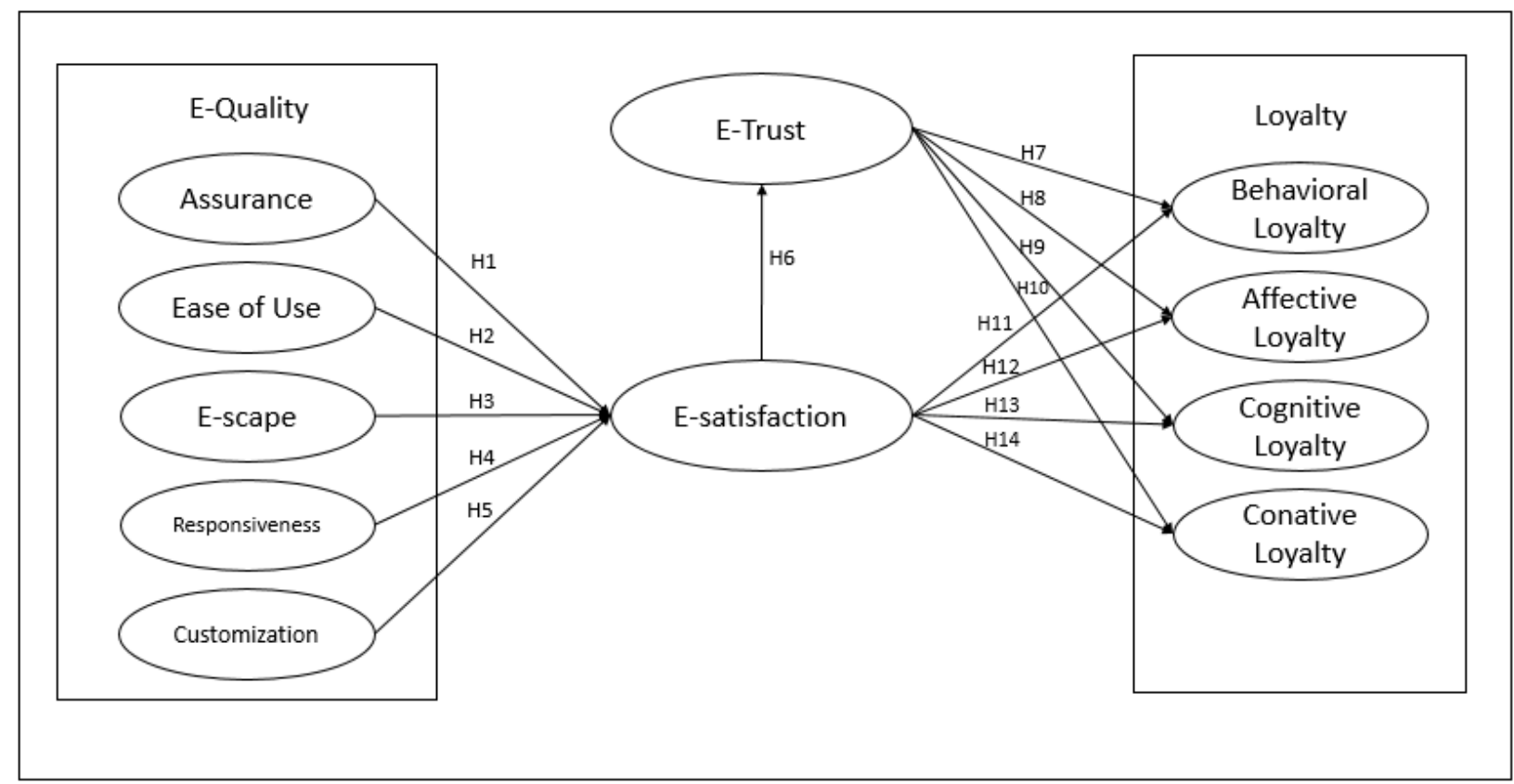

Sumber: Chou, Chen, \& Lin (2015), Ribbink et al. (2004) dan El-Manstrly et al. (2013) dengan modifikasi.

\section{METODE PENELITIAN}

Populasi dalam penelitian ini adalah konsumen yang pernah menggunakan jasa layanan Gojek. Penelitian ini menggunakan data primer dengan kuisioner terhadap 400 responden. Teknik pengambilan sampel dalam penelitian ini menggunakan purposive sampling.

Konstruk kualitas-e terdiri atas lima dimensi yaitu kemudahan penggunaan, $e$ scape, kostumisasi, daya tanggap dan jaminan yang diadospi dari Ribbink et al., (2004)danZeithaml et. al. (2000). Peubah e-satisfaction terdiri dari empat indikator yang diadopsi dari penelitianRibbink et al., (2004) danZeithaml et al. (2000).
Peubah $e$-trust terdiri dari lima indikator yang diadopsi dariRibbink et al. (2004). Kesetiaan-e pelanggan terdiri dari empat dimensi yang terdiri dari kesetiaan kognitif dengan lima indikator, loyaltas afektif dengan lima indikator, kesetiaan konatif dengan empat indikator, dan kesetiaan tindakan dengan empat indikator, yang diadopsi dari El-Manstrly \& Harrison (2013). Semua pertanyaan yang ada menggunakan 5 skala likert dari sangat tidak setuju (1) sampai sangat setuju (5).

Analisa terhadap model penelitian ini dilakukan dengan dua langkah yaitu analisis model pengukuran dan analisis model struktural. Pada analisis model 
pengukuran dilakukan uji kecocokan keseluruhan model, analisis kesahihan model dan analisis keandalanmodel. Pada analisis model strukural melakukan analisis mengenai hubungan kausal antar peubah-peubah laten melalui path diagram yang sesuai dengan model yang digunakan. Analisis SEM dilakukan dengan bantuan software LISREL.

Pada uji reliabilitas, suatu indikator yang baik adalah yang memiliki Cronbach's Alpha sebesar 0,6, dan pada uji kesahihan, suatu peubah yang baik adalah yang memiliki nilai $\mathrm{VE} \geq 0,5$.

\section{HASIL DAN PEMBAHASAN}

Dari 400 kuisioner yang disebarkan, terdapat 121 kuisioner yang dapat digunakan karena 179 responden tidak pernah menggunakan Gojek. Syarat responden tesebut layak diperhitungkan dalam penelitian ini adalah pelanggan atau orang yang pernah menggunakan Gojek sebelumnya.

Profil responden dari penelitian ini dapat dilihat pada tabel dibawah ini. Berdasarkan hasil pengolahan SPSS 24.0 , terdapat 60 responden pria $(49,6 \%)$ dan 61 wanita $(50,4 \%)$. Terdapat 9 responden berusia dibawah 20 tahun $(7,4 \%), 62$ berusia $21-30$ tahun $(51,2 \%)$,
40 responden berusia $31-40$ tahun $(33,1 \%), 9$ responden berusia 41-50 tahun $(7,4 \%)$ dan 1 orang berusia diatas 50 tahun $(0,8 \%)$. Pendidikan terakhir dari responden adalah sebagai berikut. Terdapat 74 orang responden yang memiliki pendidikan dibawah $\mathrm{S} 1$ $(61,2 \%), \quad 45$ responden yang berpendidikan $\mathrm{S} 1(37,2 \%)$ dan 2 orang responden yang berpendidikan S2 $(1,7 \%)$. Frekuensi responden menggunakan Gojek dalam enam bulan terakhir adalah 1 kali sebanyak 58 orang ( 47,9\%), 18 orang pernah mengunakan Gojek sebanyak 2 kali dalam enam bulan terakhir dan 45 orang pernah menggunakan Gojek sebanyak lebih dari 3 kali $(37,2 \%)$. Terdapat 36 responden berdomisili di wilayah Jakarta $(29,8 \%)$, 45 orang berdomisili di wilayah Tangerang (37,2\%) dan 40 orang berdomisili di wilayah diluar Jakarta dan Tangerang $(33,1 \%)$. Terdapat 66 orang yang pernah menggunakan ojek daring lainnya $(54,5 \%)$ dan 55 orang tidak pernah menggunakan ojek daring lainnya $(45,5 \%)$. Seluruh responden dari penelitian ini adalah karyawan. 


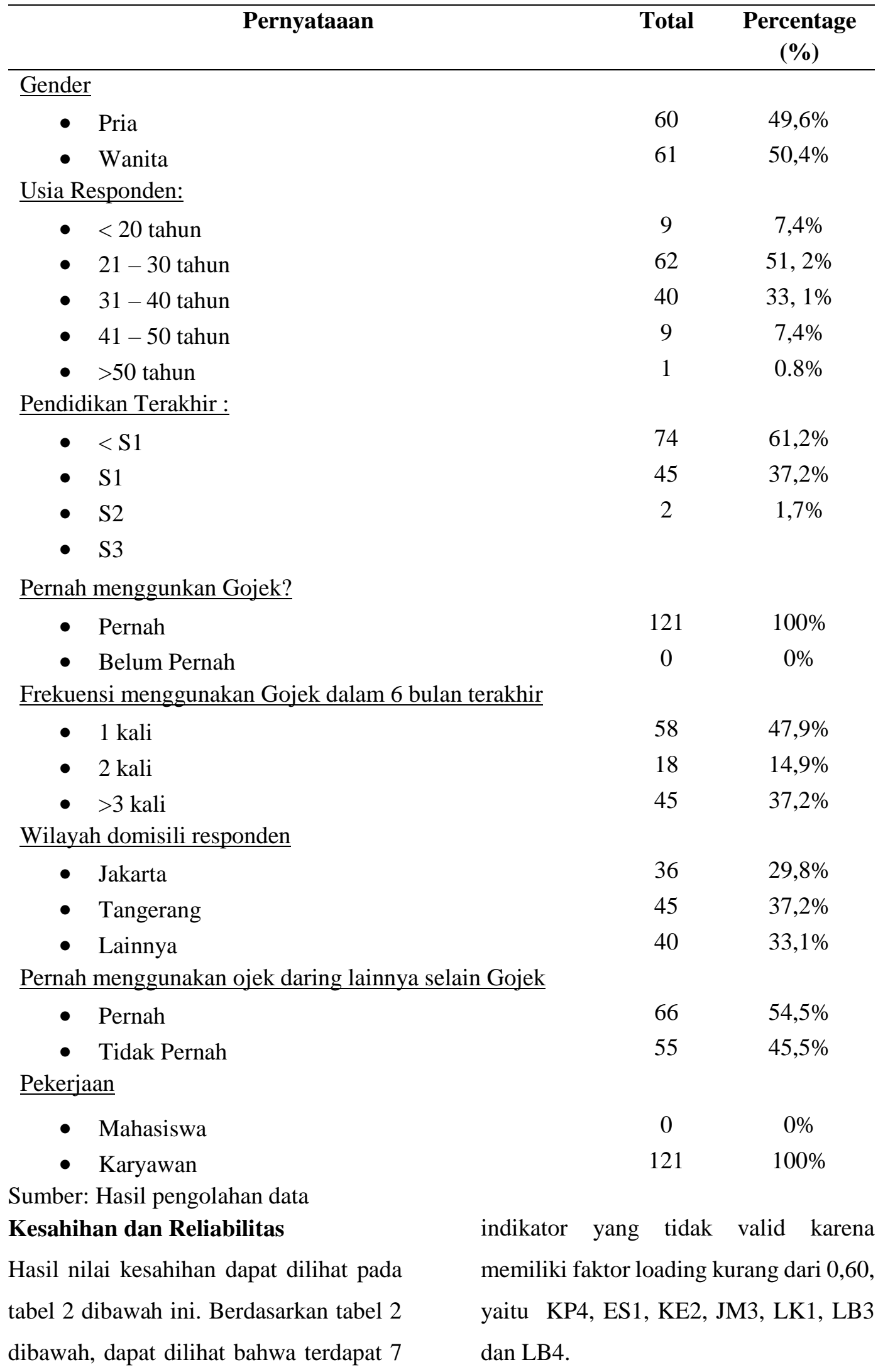


Table 2. CFA I: Kesahihan \& Keandalan

\begin{tabular}{|c|c|c|c|}
\hline & $\begin{array}{c}\text { Standarized } \\
\text { Loading Factor } \\
(\mathrm{SLF}) \geq \mathbf{0 . 6 0}\end{array}$ & $\begin{array}{c}\text { Standard } \\
\text { Errors }\end{array}$ & Keterangan \\
\hline \multicolumn{4}{|c|}{ Kemudahan Penggunaan } \\
\hline KP1 & 0.67 & 0.55 & Kesahihan baik \\
\hline KP2 & 0.75 & 0.44 & Kesahihan baik \\
\hline KP3 & 0.76 & 0.42 & Kesahihan baik \\
\hline KP4 & 0.52 & 0.73 & $\begin{array}{l}\text { Kesahihan kurang } \\
\text { baik }\end{array}$ \\
\hline \multicolumn{4}{|c|}{ e-scape } \\
\hline ES1 & 0.59 & 0.65 & $\begin{array}{c}\text { Kesahihan kurang } \\
\text { baik }\end{array}$ \\
\hline ES2 & 0.73 & 0.47 & Kesahihan baik \\
\hline ES3 & 0.75 & 0.44 & Kesahihan baik \\
\hline \multicolumn{4}{|c|}{ Keandalan } \\
\hline KE1 & 0.83 & 0.31 & Kesahihan baik \\
\hline KE2 & 0.83 & 0.31 & Kesahihan baik \\
\hline KE3 & 0.46 & 0.79 & $\begin{array}{l}\text { Kesahihan kurang } \\
\text { baik }\end{array}$ \\
\hline \multicolumn{4}{|c|}{ Kustomisasi } \\
\hline KU1 & 0.60 & 0.64 & Kesahihan baik \\
\hline KU2 & 0.65 & 0.57 & Kesahihan baik \\
\hline KU3 & 0.77 & 0.41 & Kesahihan baik \\
\hline \multicolumn{4}{|c|}{ Jaminan } \\
\hline JM1 & 0.74 & 0.46 & Kesahihan baik \\
\hline JM2 & 0.68 & 0.53 & Kesahihan baik \\
\hline JM3 & 0.57 & 0.68 & $\begin{array}{c}\text { Kesahihan kurang } \\
\text { baik }\end{array}$ \\
\hline \multicolumn{4}{|c|}{ Kepuasan } \\
\hline $\mathrm{CS} 1$ & 0.79 & 0.38 & Kesahihan baik \\
\hline $\mathrm{CS} 2$ & 0.82 & 0.33 & Kesahihan baik \\
\hline CS3 & 0.86 & 0.27 & Kesahihan baik \\
\hline $\mathrm{CS} 4$ & 0.85 & 0.28 & Kesahihan baik \\
\hline \multicolumn{4}{|c|}{ Kepercayaan } \\
\hline TR1 & 0.69 & 0.52 & Kesahihan baik \\
\hline TR2 & 0.78 & 0.39 & Kesahihan baik \\
\hline TR3 & 0.76 & 0.43 & Kesahihan baik \\
\hline TR4 & 0.83 & 0.30 & Kesahihan baik \\
\hline TR5 & 0.73 & 0.47 & Kesahihan baik \\
\hline \multicolumn{4}{|c|}{ Kesetiaan Kognitif } \\
\hline LK1 & 0.50 & 0.75 & $\begin{array}{l}\text { Kesahihan kurang } \\
\text { baik } \\
\end{array}$ \\
\hline LK2 & 0.77 & 0.40 & Kesahihan baik \\
\hline LK3 & 0.63 & 0.61 & Kesahihan baik \\
\hline LK4 & 0.84 & 0.30 & Kesahihan baik \\
\hline LK5 & 0.79 & 0.38 & Kesahihan baik \\
\hline \multicolumn{4}{|c|}{ Kesetiaan Afektif } \\
\hline LA1 & 0.78 & 0.39 & Kesahihan baik \\
\hline LA2 & 0.82 & 0.33 & Kesahihan baik \\
\hline LA3 & 0.84 & 0.30 & Kesahihan baik \\
\hline LA4 & 0.82 & 0.33 & Kesahihan baik \\
\hline LA5 & 0.65 & 0.57 & Kesahihan baik \\
\hline
\end{tabular}




\begin{tabular}{|l|c|c|c|}
\hline \multicolumn{4}{|l|}{ Kesetiaan Konatif } \\
\hline LC1 & 0.77 & 0.41 & Kesahihan baik \\
\hline LC2 & 0.77 & 0.41 & Kesahihan baik \\
\hline LC3 & 0.61 & 0.63 & Kesahihan baik \\
\hline LC4 & 0.64 & 0.59 & Kesahihan baik \\
\hline Kesetiaan Tindakan & 0.82 & 0.34 & Kesahihan baik \\
\hline LB1 & 0.83 & 0.31 & Kesahihan baik \\
\hline LB2 & 0.34 & 0.88 & $\begin{array}{c}\text { Kesahihan kurang } \\
\text { baik }\end{array}$ \\
\hline LB3 & 0.38 & 0.85 & $\begin{array}{c}\text { Kesahihan kurang } \\
\text { baik }\end{array}$ \\
\hline LB4 & & &
\end{tabular}

Sumber: Hasil olah data

Setelah indikator yang tidak valid dihapus, dan dilakukan perhitungan ulang, Hasil dari perhitungan ulang dapat dilihat pada tabel 3. CFA II: Kesahihan \& Reliailitas. Pada tabel 3 dapat dilihat bahwa semua indikator memiliki faktor loading di atas 0.60 , dimana hal ini menujukkan bahwa semua indikator valid untuk mengukur konstruknya.
Tidak ada indikator yang harus dihapus karena tidak vald. Hasil uji keandalanpada tabel 3 menunjukan semua peubah yang ada memiliki nilai $\mathrm{CR} \geq 0,70$ dan nilai $\mathrm{VE} \geq 0,50$, sehingga dapat dikatakan bahwa seluruh peubah adalah reliabel. 
Table 3. CFA II: Kesahihan \& Keandalan

\begin{tabular}{|c|c|c|c|c|c|}
\hline & \multirow{2}{*}{$\begin{array}{c}\text { Standarized } \\
\text { Loading } \\
\text { Factor }(\mathrm{SLF}) \\
\geq \mathbf{0 . 6 0}\end{array}$} & \multirow{2}{*}{$\begin{array}{c}\text { Standard } \\
\text { Errors }\end{array}$} & \multirow[t]{2}{*}{ Keterangan } & \multicolumn{2}{|c|}{ Reliabilitas } \\
\hline & & & & $\begin{array}{c}\text { CR } \\
\geq \\
0.70\end{array}$ & $\begin{array}{c}\mathrm{VE} \\
\geq \\
0.50\end{array}$ \\
\hline \multicolumn{4}{|c|}{ Kemudahan Penggunaan } & 0.788 & 0.620 \\
\hline KP1 & 0.70 & 0.52 & Kesahihan baik & & \\
\hline KP2 & 0.80 & 0.36 & Kesahihan baik & & \\
\hline KP3 & 0.73 & 0.46 & Kesahihan baik & & \\
\hline \multicolumn{4}{|c|}{ e-scape } & 0.742 & 0.777 \\
\hline ES2 & 0.60 & 0.68 & Kesahihan baik & & \\
\hline ES3 & 0.94 & 0.12 & Kesahihan baik & & \\
\hline \multicolumn{4}{|c|}{ Keandalan } & 0.822 & 0.835 \\
\hline KE1 & 0.85 & 0.27 & Kesahihan baik & & \\
\hline KE2 & 0.82 & 0.32 & Kesahihan baik & & \\
\hline \multicolumn{4}{|c|}{ Kustomisasi } & 0.718 & 0.679 \\
\hline KU1 & 0.61 & 0.63 & Kesahihan baik & & \\
\hline KU2 & 0.67 & 0.55 & Kesahihan baik & & \\
\hline KU3 & 0.75 & 0.43 & Kesahihan baik & & \\
\hline \multicolumn{4}{|c|}{ JAMINAN } & 0.710 & 0.743 \\
\hline JM1 & 0.81 & 0.35 & Kesahihan baik & & \\
\hline JM2 & 0.67 & 0.55 & Kesahihan baik & & \\
\hline \multicolumn{4}{|c|}{ Kepuasan } & 0.899 & 0.830 \\
\hline $\mathrm{CS} 1$ & 0.79 & 0.38 & Kesahihan baik & & \\
\hline $\mathrm{CS} 2$ & 0.82 & 0.33 & Kesahihan baik & & \\
\hline CS3 & 0.86 & 0.27 & Kesahihan baik & & \\
\hline $\mathrm{CS} 4$ & 0.85 & 0.28 & Kesahihan baik & & \\
\hline \multicolumn{4}{|c|}{ Kepercayaan } & 0.874 & 0.763 \\
\hline TR1 & 0.70 & 0.51 & Kesahihan baik & & \\
\hline TR2 & 0.79 & 0.38 & Kesahihan baik & & \\
\hline TR3 & 0.76 & 0.43 & Kesahihan baik & & \\
\hline TR4 & 0.83 & 0.32 & Kesahihan baik & & \\
\hline TR5 & 0.73 & 0.47 & Kesahihan baik & & \\
\hline \multicolumn{4}{|c|}{ Kesetiaan Kognitif } & 0.849 & 0.766 \\
\hline LK2 & 0.77 & 0.41 & Kesahihan baik & & \\
\hline LK3 & 0.63 & 0.59 & Kesahihan baik & & \\
\hline LK4 & 0.84 & 0.30 & Kesahihan baik & & \\
\hline LK5 & 0.80 & 0.37 & Kesahihan baik & & \\
\hline \multicolumn{4}{|c|}{ Kesetiaan Afektif } & 0.888 & 0.785 \\
\hline LA1 & 0.78 & 0.39 & Kesahihan baik & & \\
\hline LA2 & 0.82 & 0.34 & Kesahihan baik & & \\
\hline LA3 & 0.84 & 0.30 & Kesahihan baik & & \\
\hline LA4 & 0.82 & 0.33 & Kesahihan baik & & \\
\hline LA5 & 0.65 & 0.58 & Kesahihan baik & & \\
\hline \multicolumn{4}{|c|}{ Kesetiaan Konatif } & 0.793 & 0.702 \\
\hline LC1 & 0.77 & 0.41 & Kesahihan baik & & \\
\hline $\mathrm{LC} 2$ & 0.78 & 0.40 & Kesahihan baik & & \\
\hline LC3 & 0.60 & 0.64 & Kesahihan baik & & \\
\hline LC4 & 0.64 & 0.59 & Kesahihan baik & & \\
\hline \multicolumn{4}{|c|}{ Kesetiaan Tindakan } & 0.816 & 0.830 \\
\hline LB1 & 0.81 & 0.34 & Kesahihan baik & & \\
\hline LB2 & 0.85 & 0.27 & Kesahihan baik & & \\
\hline
\end{tabular}

Sumber: Hasil pengolahan data. 
Setelah semua indikator dan peubah lolos dalam pengujian validatas dan reliabilitas, selanjutnya dilakukan analisis kecocokan data dengan model secara keseluruhan atau disebut dengan Goodness of Fit (GOF). Pengujian ini bertujuan untuk mengevaluasi apakah model yang dihasilkan merupakan model fit atau tidak. Dari hasil run full model diatas, berdasarkan kriteria GOF yang ada, dimana batas p-value > 0.05 dan RMSEA < 0.08, maka GOF belum dipenuhi, disimpulkan model belum fit dengan data, karena p-value $=0.00000<$ 0.05 dan RMSEA $=0.095>0.08$. Lisrel memberikan rekomendasi menghubungkan beberapa residual dari beberapa indikator agar model menjadi fit dengan data.

Setelah dilakukan modifikasi berdasarkan rekomendasi Lisrel, maka berdasarkan kriteria GOF (Goodness-offit) yang ada, dimana batas p-value $>0.05$ dan RMSEA < 0.08, maka GOF sudah dipenuhi, disimpulkan model fit dengan data, karena RMSEA $=0.078<0.08$. Pada tabel 4 dibawah ini memberikan informasi rangkuman hasil pengujian GOF (Goodness-of-fit) pada model hasil penelitian.

Tabel 4. Uji Kecocokan Keseluruhan Model (Goodness of fit)

\begin{tabular}{|l|l|l|l|}
\hline Ukuran GOF & \multicolumn{1}{|c|}{ Target Tingkat Kecocokan } & \multicolumn{1}{c|}{ Hasil Estimasi } & \multicolumn{1}{c|}{$\begin{array}{c}\text { Tingkat } \\
\text { Kecocokan }\end{array}$} \\
\hline Chi Square $P$ & Nilai yang kecil $\mathrm{p}>0.05$ & $1198.75(\mathrm{p}=0.00)$ & Kurang baik \\
\hline NCP Interval & Nilai yang kecil interval yang sempit & 655.75 & Kurang baik \\
\hline RMSEA & RMSEA $\leq 0.08 \mathrm{p} \geq 0.50$ & $0.078(\mathrm{p}=0.0)$ & Baik (good fit) \\
\hline NFI & NFI $\geq 0.90$ & 0.91 & Baik (good fit) \\
\hline NNFI & NNFI $\geq 0.90$ & 0.94 & Baik (good fit) \\
\hline CFI & CFI $\geq 0.90$ & 0.95 & Baik (good fit) \\
\hline IFI & IFI $\geq 0.90$ & 0.95 & Baik (good fit) \\
\hline RFI & RFI $\geq 0.90$ & 0.90 & Baik (good fit) \\
\hline RMR & Standardized RMR $\leq 0.05$ & 0.042 & Baik (good fit) \\
\hline GFI & GFI $\geq 0.90$ & 0.75 & Kurang baik \\
\hline AFGI & AGFI $\geq 0.90$ & 0.69 & Kurang baik \\
\hline
\end{tabular}

Sumber: data diolah

Tabel 4 menyimpulkan hasil uji kecocokan keseluruhan model. Dari tabel diatas terdapat 4 ukuran GOF yang kurang baik dan 7 ukuran GOF menunjukan kecocokan yang baik (good fit). Sehingga dapat disimpulkan bahwa kecocokan keseluruhan model adalah baik (good fit). 


\section{Pengujian Hipotesis}

Pada tabel 5 dan gambar 1 menunjukkan hasil pengujian hipotesis dengan nilai $\alpha=0.05$ dengan batas $t$-value $\geq 1.96$. Terdapat delapan hipotesis yang tidak signifikan karena t value kurang dari 1.96 yaitu Ease of Use tidak berpengaruh positif terhadap e-kepuasan pelanggan (H1), E-scape tidak berpengaruh positif terhadap e-kepuasan pelanggan $(\mathrm{H} 2)$, Responsiveness tidak berpengaruh positif terhadap e-satisfaction (H3),
Customization tidak berpengaruh positif terhadap e-satisfaction (H4), Assurance tidak berpengaruh positif terhadap $e$ satisfaction (H5), E-trust tidak berpengaruh terhadap behavioral loyalty (H7), E-trust tidak berpengaruh terhadap affective loyalty (H8), E-trust berpengaruh terhadap cognitive loyalty (H9), dan E-trust tidak berpengaruh terhadap conative loyalty (H10). Sedangkan kelima hipotesis lainnya signifikan karena t value lebih besar 1.96 .

Tabel 5.Structural Models Results

\begin{tabular}{|c|c|c|c|}
\hline Hypothesis & Path & $\mathrm{t}$ value & Hasil \\
\hline $\mathrm{H}_{1}$ & Ease of Use $\rightarrow e$-satisfaction. & 0.43 & $\begin{array}{c}\text { Tidak } \\
\text { signifikan } \\
\end{array}$ \\
\hline $\mathrm{H}_{2}$ & E-scape $\rightarrow e$-satisfaction. & 0.32 & $\begin{array}{c}\text { Tidak } \\
\text { signifikan }\end{array}$ \\
\hline $\mathrm{H}_{3}$ & Responsiveness $\rightarrow e$-satisfaction. & -0.67 & $\begin{array}{c}\text { Tidak } \\
\text { signifikan } \\
\end{array}$ \\
\hline $\mathrm{H}_{4}$ & Customization $\rightarrow e$-satisfaction. & 0.15 & $\begin{array}{c}\text { Tidak } \\
\text { signifikan } \\
\end{array}$ \\
\hline H5 & Assurance $\rightarrow e$-satisfaction. & 0.27 & $\begin{array}{c}\text { Tidak } \\
\text { signifikan }\end{array}$ \\
\hline $\mathrm{H}_{6}$ & E-satisfaction $\rightarrow e$-trust. & 8.08 & Signifikan * \\
\hline $\mathrm{H}_{7}$ & E-trust $\rightarrow$ behavioral loyalty. & 1.56 & $\begin{array}{c}\text { Tidak } \\
\text { signifikan } \\
\end{array}$ \\
\hline H8 & E-trust $\rightarrow$ affective loyalty. & -0.85 & $\begin{array}{c}\text { Tidak } \\
\text { signifikan } \\
\end{array}$ \\
\hline H9 & E-trust $\rightarrow$ cognitive loyalty. & 0.83 & $\begin{array}{c}\text { Tidak } \\
\text { signifikan }\end{array}$ \\
\hline H10 & E-trust $\rightarrow$ conative loyalty & 1.54 & $\begin{array}{c}\text { Tidak } \\
\text { signifikan }\end{array}$ \\
\hline H11 & E-satisfaction $\rightarrow$ behavioral loyalty & 4.68 & Signifikan * \\
\hline H12 & E-satisfaction $\rightarrow$ affective loyalty. & 4.72 & Signifikan * \\
\hline H13 & E-satisfaction $\rightarrow$ cognitive loyalty. & 3.81 & Signifikan * \\
\hline H14 & E-satisfaction $\rightarrow$ conative loyalty. & 4.96 & Signifikan * \\
\hline
\end{tabular}

Sumber: Hasil pengolahan data. 


\section{Gambar 1. Structural Model Estimates}

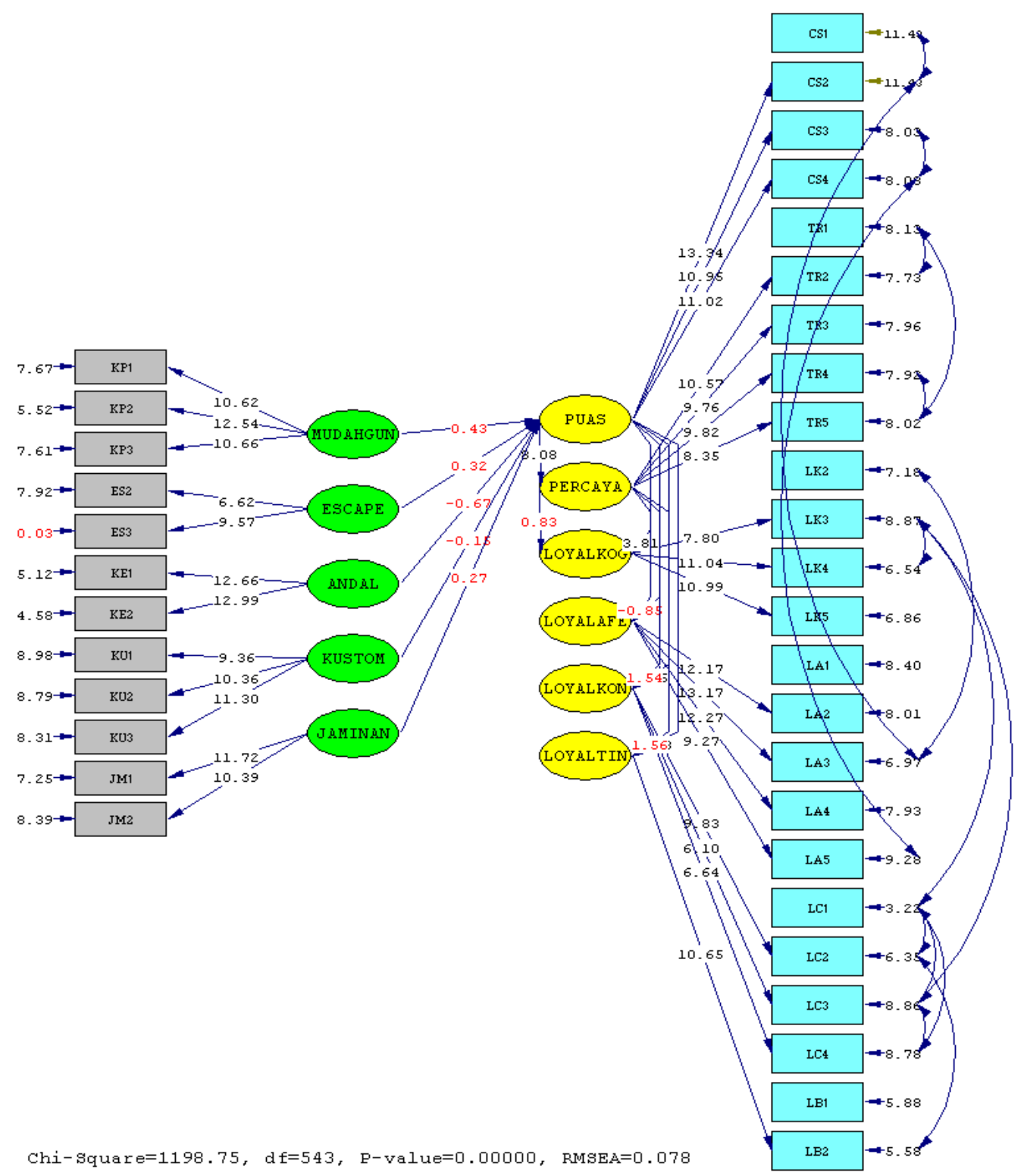

Sumber: Output Lisrel hasil olahan peneliti

\section{Analisis dan Pembahasan}

Hasil pengujian hipotesis pertama menunjukkan bahwa Ease of Use tidak berpengaruh positif terhadap $e$ satisfaction. Hasil pengujian ini tidak mendukung atau tidak konsisten dengan hasil penelitian-penelitian sebelumnya bahwa Ease of use berpengaruh positif terhadap e-satisfaction. Berdasarkan hasil rata-rata dari item pertanyaan dari peubah ease of use menunjukkan bahwa tingkat kemudahan dari penggunaan aplikasi Gojek adalah cukup tinggi. Hanya saja walaupun kualitas pelayanan 
yang diberikan oleh Gojek dalam hal kemudahan penggunaan adalah cukup baik, hal itu tidak menjamin bahwa pelanggan puas dengan layanan yang diberikan oleh Gojek.

Hasil pengujian hipotesis yang kedua menunjukkan bahwa E-scapetidak berpengaruh positif terhadap $e$ satisfaction. Berdasarkan hasil rata-rata dari jawaban responden terhadap indikator e-scape yang ada menunjukkan bahwa responden merasa netral terhadap e-scape dari Gojek. Hal ini menunjukkan bahwa responden tidak terlalu mempermasalahkan mengenai tampilan, layout, warna dan design dari aplikasi Gojek, sehingga hal tersebut tidak menjadi hal yang penting atau material bagi responden pengguna Gojek. Tingkat pendidikan responden $61,2 \%$ berpendidikan dibawah $\mathrm{S}$, dapat juga menunjukkan bahwa e-scape tidak merupakan hal yang penting bagi mereka. Responden lebih menitikberatkan pada utilitas Gojek dibandingkan dengan tampilan, design, warna dan layout dari aplikasi Gojek untuk menentukan kepuasan mereka.

Hasil pengujian hipotesis ketiga menunjukkan bahwa Responsivenesstidak berpengaruh positif terhadap e-satisfaction. Hasil rata-rata dari jawaban responden terhadap indikator keandalan menunjukkan bahwa responden merasa netral terhadap keandalan dari Gojek. Keandalan yang diberikan Gojek seperti kemudahan berkontak, ketertarikan Gojek terhadap umpan balik, menunjukkan bahwa kualitas layanan yang diberikan oleh Gojek dalam hal kemudahan berkontak dan ketertarikan Gojek terhadap umpan balik belumlah maksimal, sehingga hal ini mengakibatkan bahwa responsiveness tidak berhubungan positif dengan kepuasan.

$$
\text { Hasil pengujian hipotesis }
$$
keempat menunjukkan bahwa Customizationtidak berpengaruh positif terhadap e-satisfaction. Nilai rata-rata dari kustomisasi menunjukkan bahwa kustomisasi bukanlah hal penting bagi responden Gojek untuk menunjukkan kepuasan mereka terhadap kualitas layanan Gojek. Profil pendidikan terakhir dari responden yang $61,2 \%$ adalah dibawah S1 menunjukkan bahwa mereka lebih mementingkan pada utilitas atau manfaat yang diberikan oleh Gojek dan tidak begitu mempedulikan dimensi kualitas layanan Gojek yaitu customization.

Hasil pengujian hipotesis kelima menunjukkan bahwa Assurancetidak berpengaruh positif terhadap $e$ satisfaction. Berdasarkan hasil penelitian menunjukkan bahwa pelaksanaan dimensi kualitas jasa jaminan atau assurance oleh Gojek belum terlihat optimal karena pelaksanaanya berada 
pada kategori cukup. Pada indikator pertanyaan kepada responden mengenai keamanan dalam sistem pembayaran daring dan kepercayaan responden terhadap Gojek menunjukkan bahwa responden cukup percaya terhadap sistem pembayaran daring Gojek dan kepercayaan terhadap Gojek, akan tetapi hal tersebut tidak cukup untuk membuktikan bahwa dimensi jaminan dari kualitas jasa berpengaruh terhadap $e$ satisfaction.

Hasil pengujian hipotesis keenam menunjukkan bahwa $E$ satisfaction berpengaruh terhadap $e$ trust. Hasil pengujian ini konsisten dengan hasil penelitian-penelitian sebelumnya mengenai $e$-satisfaction dan e-trustpada industri perbankan di Malaysia (Yap et al., 2012), industri restoran (Bowden-Everson et al., 2013).

Hasil pengujian hipotesis ketujuh sampai sepuluh menunjukkan bahwa E-trusttidak berpengaruh terhadap behavioral loyalty, affective loyalty, cognitive loyalty, dan conative loyalty. Nilai rata-rata keempat dimensi kesetiaan menunjukkan bahwa tingkat kesetiaan mereka adalah cukup rendah yaitu sebesar 3,35-3,50. Hal ini juga didukung oleh profil responden yaitu frekuensi penggunaan selama 6 bulan terakhir yaitu sebanyak $\quad 47,9 \% \quad$ responden menggunakan Gojek hanya 1 kali selama 6 bulan dan 54,5\% responden pernah menggunakan transportasi daring lainnya selain Gojek. Hal ini menunjukkan bahwa profil responden pengguna Gojek pada penelitian ini adalah kurang loyal atau kurang fanatik pada satu merek transportasi daring saja. Selain itu, seperti yang kita ketahui switching cost ketika seorang pelangan berpindah ke transportasi daring lainnya juga rendah, sehingga biaya peralihan bukanlah hal yang menjadi kendala yang mengharuskan seorang pelanggan untuk tetap setia pada suatu layanan transportasi daring. Penelitian Herington $\&$ Weaven (2007) juga menunjukkan tidak ada hubungan antara $e$-trust dan $e$ loyalty pada penguna daring banking di Australia.

Hasil pengujian hipotesis kesebelas, sampai keempat belas menunjukkan bahwa E-satisfaction berpengaruh terhadap behavioral loyalty, affective loyalty, cognitive loyalty dan conativeloyalty. Hasil pengujian ini sesuai dengan penelitian sebelumnya yang dilakukan pada industry perhotelan di Indonesi (Suhartanto, 2011), industry retail yang menjual pakaian secara daring di Taiwan (Chou et al., 2015) dan industry perbankan di Malaysia (Amin, 2016).

\section{SIMPULAN DAN IMPLIKASI}

Berdasarkan hasil analisa dan pengolahan data, maka beberapa 
simpulan yang dapat ditarik dalam penelitian ini adalah:

1. Kualitas layanan-e yang terdiri dari 5 dimensi yaitu kemudahan penggunaan, $e$-scape, keandalan, kustomisasi dan jaminan tidak berpengaruh positf terhadap kepuasan-e

2. Kepuasan-e berpengaruh terhadap kepercayaan-e

3. Kepercayaan-e tidak berpengaruh terhadap perilaku, afektif, kognitif dan kesetiaan konatif.

4. Kepuasan-e berpengaruh terhadap perilaku, afektif, kognitif dan kesetiaan konatif.

Penelitian ini memiliki implikasi teoritis dan managerial. Implikasi teoritisnya adalah dimensi kualitas layanan-e yang digunakan dalam penelitian ini tidak berpengaruh signifikan terhadap kepuasan-e pada transportasi ojek daring, terutama Gojek. Kedepanya dapan mengunakan dimensi kualitas layanan-e lainnya dari bisnis daring. Kepercayaane tidak berpengaruh terhadap empat dimensi dari kesetiaan, yaitu perilaku, afektif, kognitif, dan afektif konatif pada transportasi ojek daring.

Sedangkan implikasi managerial dari penelitian ini adalah kelima dimensi kualitas layanan-e yang ada tidak menunjukkan pengaruh terhadap kepuasan-e. Manajemen Gojek harus memikirkan kualitas layanan lainnya yang dapat membuat pelanggan puas dengan menggunakan Gojek. Nilai ratarata dari kepercayan responden terhadap Gojek menunjukan nilai tertingi 3,5. Hal ini menunjukkan bahwa tingkat kepercayaan responden belum terlalu tinggi. Manajemen Gojek harus memikirkan bagaimana cara untuk meningkatkan kesetiaan pelangannya dan membuat mereka untuk tidak beralih menggunakan jasa layanan ojek lainnya.

\section{KETERBATASAN DAN REKOMENDASI}

Keterbatasan pada penelitian ini adalah tidak menggunakan harga sebagai salah satu peubah yang diteliti. Untuk kedepannya direkomendasikan untuk menambahkan peubah harga mengingat pengguna ojek memiliki karakteristik yang peduli dan sensitif terhadap harga. Rekomendasi lainnya adalah menggunakan responden yang memiliki latar belakang pendidikan minimal S1. Karena dalam penelitian ini respondennya adalah orang yang telah bekerja dan sebagian besar berpendidikan di bawah S1 dan tidak terlalu peduli dengan kualitas layanan yang diberikan oleh Gojek. 


\section{DAFTAR PUSTAKA}

Amin, M. (2016). Internet banking service quality and its implication on e-customer satisfaction and ecustomer loyalty. International Journal of Bank Marketing, 34(3), 280-306.

Anderson, R. E., \& Srinivasan, S. S. (2003). E-Satisfaction and ELoyalty: A Contingency Framework. Psychology and Marketing, 20(2), 123-138. http://doi.org/10.1002/mar.10063

Bart, Y., Shankar, V., Sultan, F., \& Urban, G. L. (2005). Are the Drivers and Role of Daring Trust the Same for All Web Sites and Consumers? A Large-Scale Exploratory Empirical Study. Journal of Marketing, 69(4), 133152.

http://doi.org/10.1509/jmkg.2005.6 9.4 .133

Bowden-Everson, J. L.-H., Dagger, T. S., \& Elliott, G. (2013). Engaging Customers for Loyalty in the Restaurant Industry: The Role of Satisfaction, Trust, and Delight. Journal of Foodservice Business Research, 16(1), 52-75. http://doi.org/10.1080/15378020.2 013.761025

Chou, S., Chen, C.-W., \& Lin, J.-Y. (2015). Female daring shoppers: Examining the mediating roles of esatisfaction and e- trust on e-loyalty development. Internet Research, 25(4), 542-561. http://doi.org/http://dx.doi.org/10.1 108/JEIM-07-2014-0077

CSR Indonesia (2015) Nielsen: Belanja Iklan Jasa Layanan Daring di Televisi Catat Pertumbuhan Luar Biasa. http://csrindonesia.com/2015/08/nielsenbiasa-iklan-jasa-layanan-daring-di- televisi-catat-pertumbuhan-luarbiasa/)

Collier, J. E., \& Bienstock, C. C. (2006). Measuring Service Quality in ERetailing. Journal of Service Research, 8(3), 260-275. http://doi.org/10.1177/1094670505 278867

Connolly, R., \& Bannister, F. (2007). Consumer Trust in Electronic Commerce: Social \& Technical Antecedents. World Academy of Science, Engineering and Technology, 2(4), 239-248.

Corritore, C. L., Kracher, B., \& Wiedenbeck, S. (2003). On-line trust: Concepts, evolving themes, a model. International Journal of Human Computer Studies, 58(6), 737-758.

http://doi.org/10.1016/S10715819(03)00041-7

Cyr, D. (2008). Modeling Website Design across Cultures: Relationships to Trust, Satisfaction and E-loyalty. Journal of Management Information Systems, 24(4), 47-72.

Dabholkar, P. A., Thorpe, D. I., \& Rentz, J. O. (1996). A Measure of Service Quality for Retail Stores: Scale Development and Validation. Journal of the Academy of Marketing Science.

Davis, F. D. (1989). Perceived Usefulness, Perceived Ease of Use, and User Acceptance of Information Technology. MIS Quarterly, 13(3), 319-340. http://doi.org/10.2307/249008

El-Manstrly, D., \& Harrison, T. (2013). A critical examination of service loyalty measures. Journal of Marketing Management, 29(1516),

1834-1861. 
http://doi.org/10.1080/0267257X.2 013.803139

Ennew, C., \& Sekhon, H. (2007). Measuring trust in financial services: The Trust Index. Consumer Policy Review, 17(2), 62.

Fang, Y.-H., Chiu, C.-M., \& Wang, E. T. G. G. (2011). Understanding customers' satisfaction and repurchase intentions: An integration of IS success model, trust, and justice. Internet Research, 21(4), 479-503. http://doi.org/10.1108/1066224111 1158335

Ganguly, B., Dash, S. B., \& Cyr, D. (2009). Website characteristics , Trust and purchase intention in daring stores : - An Empirical study in the Indian context. Journal of Information Science and Technology, 6(January 2009), 2244.

Garbarino, E., \& Strahilevitz, M. (2004). Gender differences in the perceived risk of buying daring and the effects of receiving a site recommendation. Journal of Business Research, 57(7), $\quad$ 768-775. http://doi.org/10.1016/S01482963(02)00363-6

Garland, R., \& Gendall, P. (2004). Testing dick and basu's customer loyalty model. Australasian Marketing Journal, 12(3), 81-87. http://doi.org/10.1016/S14413582(04)70108-1

Gounaris, S., Dimitriadis, S., \& Stathakopoulos, V. (2010). An examination of the effects of service quality and satisfaction on customers' behavioral intentions in e-shopping. Journal of Services Marketing, 24(2), 142-156. http://doi.org/10.1108/0887604101 1031118

Grabner-Kräuter, S., \& Faullant, R.
(2008). Consumer acceptance of internet banking: the influence of internet trust. International Journal of Bank Marketing, 26(7), 483-504. http://doi.org/10.1108/0265232081 0913855

Hansemark, O. C., \& Albinsson, M. (2004). Customer satisfaction and retention: the experiences of individual employees. Managing Service Quality, 14(1), 40-57. http://doi.org/10.1108/0960452041 0513668

Hennig-Thurau, T., Gwinner, K. P., \& Gremler, D. D. (2002). Understanding Relationship Marketing Outcomes: An Integration of Relational Benefits and Relationship Quality. Journal of Service Research, 4(3), 230-247. http://doi.org/10.1177/1094670502 004003006

Herington, C., \& Weaven, S. (2007). Can banks improve customer relationships with high quality daring services? Managing Service Quality, 17(4), 404-427. http://doi.org/10.1108/0960452071 0760544

Ibrahim, E. N. M., Noor, N. L. M., \& Mehad, S. (2009). Trust or distrust in the web-mediated information environment (W-MIE): A perspective of daring Muslim users. Journal of Enterprise Information Management, 22(5), 523-547. http://doi.org/10.1108/1741039091 0993527

Jun, M., Yang, Z., \& Kim, D. (2004). Customers' perceptions of daring retailing service quality and their satisfaction. International Journal of Quality \& Reliability Management, 21(8), 817-840. http://doi.org/10.1108/0265671041 0551728

Kang, B.-S., Cho, C.-H., \& Baek, J.-D. 
(2007). The Effects of Service Quality on Customer Satisfaction in Case of Dissatisfied Customers. Asian Journal on Quality, 8(1), 2739.

http://doi.org/10.1108/1598268820 0700003

Kesharwani, A., \& Bisht, S. S. (2012). The impact of trust and perceived risk on internet banking adoption in India: An extension of technology acceptance model. International Journal of Bank Marketing, 30(4), 303-322.

http://doi.org/10.1108/0265232121 1236923

Komiak, S. X., \& Benbasat, I. (2004). Understanding Customer Trust in Agent-Mediated Electronic Commerce, Web-Mediated Electronic Commerce, and Traditional Commerce. Information and Technology Management, 5(1/2), 181-207. http://doi.org/10.1023/B:ITEM.000 0008081.55563.d4

Kumar, V., \& Shah, D. (2004). Building and sustaining profitable customer loyalty for the 21st century. Journal of Retailing, 80(4), 317-330. http://doi.org/10.1016/j.jretai.2004. 10.007

Kursunluoglu, E. (2014). Shopping centre customer service: creating customer satisfaction and loyalty. Marketing Intelligence \& Planning, 32(4), 528-548. http://doi.org/10.1108/MIP-112012-0134

Levy, M., Weitz, B. ., \& Beitelspacher, L. . (2011). Retailing Management (8th ed.). New york: McGraw-Hill.

Liu, C., Marchewka, J. T., Lu, J., \& Yu, C. S. (2005). Beyond concern-a privacy-trust-behavioral intention model of electronic commerce. Information and Management,
$42(2)$,

289-304.

http://doi.org/10.1016/j.im.2004.01

.003

Lu, L.-C., Chang, H.-H., \& Yu, S.-T. (2013). Daring shoppers' perceptions of e- retailers' ethics, cultural orientation, and loyalty. Internet Research, 23(1), 47-68. http://doi.org/10.1108/1066224131 1295773

Milne, G. R., \& Rohm, A. J. (2000). Consumer Privacy and Name Removal Across Direct Marketing Channels: Exploring Opt-In and Opt-Out Alternatives. Journal of Public Policy \& Marketing, 19(2), 238-249. http://doi.org/10.1509/jppm.19.2.2 38.17136

Miranda, M. J., Kónya, L., \& Havrila, I. (2005). Shoppers' satisfaction levels are not the only key to store loyalty. Marketing Intelligence \& Planning, 23(2), 220-232. http://doi.org/10.1108/0263450051 0589958

Mukherjee, A., \& Nath, P. (2007). Role of Electronic Trust in Daring Retailing: A Re-Examination of The commitment-trust theory. European Journal of Marketing (Vol. 41). http://doi.org/10.1108/0309056071 0773390

Okezone (2015). 10 Jasa Transportasi Daring di Indonesia, dari Go-Jek hingga Uber. (http://economy.okezone.com/read/ 2015/09/23/320/1219859/10-jasatransportasi-daring-di-indonesiadari-go-jek-hingga-uber)

Oliver, R. (1997). Satisfaction: A Behavioral Perspective on the Consumer. New york: McGrawHill.

Oliver, R. L. (1999). Whence consumer 
loyalty? Journal of Marketing, 63(1999), 33-44. http://doi.org/10.2307/1252099

Papadopoulou, P., Andreou, A., Kanellis, P., \& Martakos, D. (2001). Trust and relationship building in electronic commerce. Internet Research: Electronic Networking Applications and Policy, 11(4), 322-332.

http://doi.org/10.1108/1066224011 0402777

Parasuraman, A., Zithaml, V., \& Berry, L. (1988). SERVQUAL: A Multiple-Item Scale for Measuring Consumer Perceptions of Service Quality. Journal of Retailing, 64(1), $12-40$.

Pavlou, P. A., \& Fygenson, M. (2006). Understanding and Predicting Electronic Commerce Adoption: An Extension of The Theory of Planned Behavior. MIS Quarterly, 30(1), 115-143.

Reibstein, D. J. (2002). What Attracts Customers to Daring Stores, and What Keeps Them Coming Back? Journal of the Academy of Marketing Science, 30(4), 465-473. http://doi.org/10.1177/0092070022 36918

Ribbink, D., Riel, A. C. R. Van, Liljander, V., \& Streukens, S. (2004). Comfort your daring customer: quality, trust and loyalty on the internet. Managing Service Quality, 14(6), 446-456. http://doi.org/10.1108/0960452041 0569784

Rust, R. T., \& Kannan, P. K. (2003). EServices: A New Paradign for Business in the Electronic Environment. Communications of the ACM, 46(6), 36-42. http://doi.org/10.1145/777313.777 336
Scullion, M., \& Nicholas, D. (2001). The Impact of the Web on the Stockbroking Industry: Big Bang 2. In Aslib Proceedings Vol 53 Iss 1 (pp. 3-22).

Shankar, V., Smith, A., \& Rangaswamy, a. (2003). Customer satisfaction and loyalty in daring and offline environments. International Journal of Research in Marketing, 20(2), 153-175. http://doi.org/10.1016/S01678116(03)00016-8

Shukla, P. (2014). The impact of organizational efforts on consumer concerns in an daring context. Information and Management, 51(1), 113-119. http://doi.org/10.1016/j.im.2013.11 .003

Srinivasan, S. S., Anderson, R., \& Ponnavolu, K. (2002). Customer loyalty in e-commerce: An exploration of its antecedents and consequences. Journal of Retailing, 78(1), $\quad$ 41-50. http://doi.org/10.1016/S00224359(01)00065-3

Suhartanto, D. (2011). An Examination of Brand Loyalty in the Indonesian Hotel Industry. Lincoln University.

Szymanski, M. D., \& Hise, T. R. (2000). E-satisfaction: an initial examination. Journal of Retailing, 76(3), 309-322.

Tam, J. L. M. (2012). The moderating role of perceived risk in loyalty intentions: an investigation in a service context. Marketing Intelligence \& Planning, 30(1), 
33-52.

http://doi.org/10.1108/0263450121 1193903

Unsal, F., \& Hormoz, M. (2001). Impact of Internet on Financial Services Industry: A Case Study of On-line Investing. Managerial Finance, 27(7), 54-65.

Utami, S. (2015). The Influence of Customer Truston Customer Loyalty. International Journal of Economics, Commerce and Management, III(7), 638-653.

Venkatesh, V., \& Davis, F. (2000). A theoretical extension of the Technology Acceptance Model: Four longitudinal field studies. Management Science, 46(2), 186204.

http://doi.org/WOS:000086130700 002

Wulf, K. De, Odekerken-Schröder, G., \& Iacobucci, D. (2001). Investments in Consumer Relationships: A Cross-Country and Cross-Industry Exploration. Journal of Marketing, 65(4), 33-50. http://doi.org/10.1509/jmkg.65.4.3 3.18386

Xue, M., \& Harker, P. T. (2002). Customer Efficiency: Concept and Its Impact on E-Business Management. Journal of Service Research, 4(4), 253-267.

Yang, Z., \& Fang, X. (2004). Daring service quality dimensions and their relationships with satisfaction: A content analysis of customer reviews of securities brokerage services. International Journal of Service Industry Management, 15(3), 302-326. http://doi.org/10.1108/0956423041 0540953

Yap, B. W., Ramayah, T., \& Wan Shahidan, W. N. (2012).
Satisfaction and trust on customer loyalty: a PLS approach. Business Strategy Series, 13(4), 154-167. http://doi.org/10.1108/1751563121 1246221

Zeithaml, V. a. (2002). Service excellence in electronic channels. Managing Service Quality, 12(3), 135-139.

http://doi.org/10.1108/0960452021 0429187

Zeithaml, V., Parasuraman, A., \& Malhotra, A. (2000). A conceptual framework for understanding $e$ service quality: implications for future research and managerial practice (No. 00-115). Cambridge, MA.

\section{UCAPAN TERIMA KASIH}

Penelitian ini didukung oleh Universitas

Pelita Harapan lewat skema penelitian

Fakultas Ekonomi No. R.

\section{4/ORP/II/2016}


